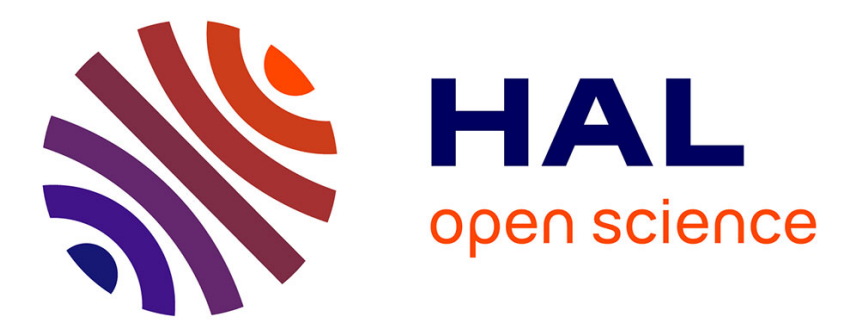

\title{
Uptake and elimination of brevetoxin in the invasive green mussel, Perna viridis, during natural Karenia brevis blooms in southwest Florida
}

Katherine Mcfarland, Fred Jean, Philippe Soudant, Aswani K. Volety

\section{- To cite this version:}

Katherine Mcfarland, Fred Jean, Philippe Soudant, Aswani K. Volety. Uptake and elimination of brevetoxin in the invasive green mussel, Perna viridis, during natural Karenia brevis blooms in southwest Florida. Toxicon, 2015, 97, pp.46-52. 10.1016/j.toxicon.2015.02.005 . hal-01145560

\author{
HAL Id: hal-01145560 \\ https://hal.science/hal-01145560
}

Submitted on 6 May 2015

HAL is a multi-disciplinary open access archive for the deposit and dissemination of scientific research documents, whether they are published or not. The documents may come from teaching and research institutions in France or abroad, or from public or private research centers.
L'archive ouverte pluridisciplinaire $\mathbf{H A L}$, est destinée au dépôt et à la diffusion de documents scientifiques de niveau recherche, publiés ou non, émanant des établissements d'enseignement et de recherche français ou étrangers, des laboratoires publics ou privés. 


\title{
Uptake and elimination of brevetoxin in the invasive green mussel, Perna viridis, during natural Karenia brevis blooms in southwest Florida
}

\author{
Katherine McFarland ${ }^{\mathrm{a}, \mathrm{b}}$ kmcfarland@fgcu.edu, Fred Jean ${ }^{\mathrm{b}}$ fjean@ univ-brest.fr, Philippe \\ Soudant ${ }^{\mathrm{b}}$ philippe.soudant@univ-brest.fr, Aswani K. Volety ${ }^{\mathrm{a}, \mathrm{c}}$ voletya@uncw.edu
}

\begin{abstract}
${ }^{a}$ Department of Marine and Ecological Sciences, Florida Gulf Coast University, 10501 FGCU Blvd. South, Fort Myers, FL 33965, USA

b LEMAR UMR 6539, Institute Universitaire Européen de la Mer, Université de Bretagne Occidentale, Rue Dumont d'Urville, Place Nicolas Copernic, 29280 Plouzané, France

${ }^{\mathrm{c}}$ Department of Biology and Marine Biology, University of North Carolina Wilmington, 601 South College Rd., Wilmington, NC, 28403, USA (current address)
\end{abstract}

Correspondence: Katherine McFarland; email: mcfarland.316@gmail.com; phone: 440-567-7335

\section{Abstract}

Perna viridis is a recently introduced species to US coastal waters and have vigorously spread throughout the southeastern seaboard since their invasion. Little information regarding their response to local environmental factors has been reported including responses to the local HAB species, Karenia brevis. This study monitored the tissue toxin concentration of brevetoxins in $P$. viridis from existing populations throughout two consecutive natural $K$. brevis blooms. The results showed $P$. viridis to rapidly accumulate $\mathrm{PbTx}$ upon exposure to the bloom, far exceeding the peak tissue concentrations of oysters, Crassostrea virginica, sampled during the same period, $57,653 \pm 15,937$ and 33,462 $\pm 10,391 \mathrm{ng} \mathrm{g}^{-1} \mathrm{PbTx}-3$ equivalent respectively. Further, $P$. viridis retained high $\mathrm{PbTx}$ concentrations in their tissues post bloom remaining above the regulatory limit for human consumption for $4-5$ months, significantly longer than the depuration time of 2 -8 weeks for native oyster and clam species. In the second year, the bloom persisted at high cell concentrations resulting in prolonged exposure and higher $\mathrm{PbTx}$ tissue concentrations indicating increased bioaccumulation in green mussels. While this species is not currently harvested for 
human consumption, the threat for post bloom trophic transfer could pose negative impacts on other important fisheries and higher food web implications.

Key Words: red tide, oyster, bioaccumulation, trophic transfer, harmful algal bloom, depuration

Abbreviations: PbTx, brevetoxin; HAB, harmful algal bloom; STX, saxitoxin; NSP, neurotoxic shellfish poisoning

\section{Introduction}

Red tide events occur regularly in the Gulf of Mexico, with the first recorded event in 1844 (Lasker and Smith, 1954) and identified as Karenia brevis in 1946 (Davis, 1948). This unarmored dinoflagellate produces a suite of neurotoxins known as brevetoxins (PbTx), which cause massive fish kills, marine mammal and seabird mortalities and neurotoxic shellfish poisoning (NSP) in humans through consumption of toxic shellfish (Ray and Wilson, 1957; McFarren et al. 1965; Adams et al., 1968; Forrester et al., 1977; Baden, 1989; Stiedinger, 1973; Flewelling et al. 2005; Naar et al., 2007; Landsberg et al., 2009). Over the past several decades outbreaks of $K$. brevis blooms have increased in frequency and duration due to eutrophication of coastal waters through anthropogenic input (Brand and Compton, 2007).

Bivalve molluscs bioaccumulate PbTx through normal filter feeding behavior with little to no mortality and, as a consequence, pose a threat to both human consumers and natural marine predators including whelks, crab, and fish (Tester et al., 2000; Brand et al., 2012). Several studies have demonstrated the transfer of PbTx from bivalves to whelks and fish (Ingham et al., 1986; Peirce et al., 2002; Naar et al., 2007; Bricelj et al., 2012). Shellfish beds are monitored regularly for both $K$. brevis cell counts and tissue toxin concentration, particularly during and green mussel, Perna viridis, during natural Karenia brevis blooms in southwest Florida. Toxicon 97: 46-52 
following bloom events. Closure of shellfish harvesting is required if $K$. brevis cell counts exceed 5,000 cells L ${ }^{-1}$ or shellfish tissue concentrations exceed $800 \mathrm{ng} \mathrm{g}^{-1} \mathrm{PbTx}-3$ equivalent brevetoxin (Plakas et al., 2008).

The green mussel, Perna viridis, is a recently introduced species to southwest Florida. The extent to which PbTx accumulates and persists in their tissues remains to be elucidated and is not monitored. If $\mathrm{PbTx}$ remains sequestered in tissues after bloom dissipation this poses a threat to predators including commercially important crab and fish, subsequently transferring toxins through the trophic web even long after a red tide event has subsided. Stomach content analyses in post bloom fish and dolphin mortalities have revealed fish with high levels of $\mathrm{PbTx}$ (Flewelling et al., 2005) and seabirds with toxic clams in the gut (Forrester et al., 1977) indicating a lethal dose through trophic transfer (Landsberg et al., 2009). Likewise, dead burrfish (Chilomycterus schoepfi) collected during a red tide bloom had the remains of toxic bivalves in their stomachs (Naar et al., 2007). While green mussels are not harvested locally for human consumption, they are an edible species and may pose potential human health concerns.

Accumulation of PbTx has been reported in the green lipped mussel, Perna canaliculus, during exposure to Karenia selliformis blooms (Morohashi et al., 1995; Ishida et al., 2004a, 2004b), however no published information directly addresses the accumulation of $\mathrm{PbTx}$ from $K$. brevis blooms in $P$. viridis. Therefore, the goal of this study was to assess the rate of $\mathrm{PbTx}$ uptake and elimination in $P$. viridis during a naturally occurring $K$. brevis bloom. This was accomplished through monthly collections from a population, which had become established in southwest Florida, before, during and after a red tide event in Estero Bay, Florida over a two year study period. 


\section{Material and Methods}

\subsection{Collection of Perna viridis}

Perna viridis of an average length of $74.3 \pm 7.3 \mathrm{~mm}$ were collected by SCUBA diving from Estero Bay, Florida at New Pass Bridge (26²2'40.89"N; 8151'39.69"W) or Big Carlos Bridge $\left(26^{\circ} 24^{\prime} 15.44 " \mathrm{~N} ; 81^{\circ} 52^{\prime} 49.64^{\prime \prime W}\right)$ once a month from October 2011 through October 2013 ( $\mathrm{N}=5$ / month). Immediately following collections mussels were cleaned of epiphytic growth, soft tissue was dissected from the shell and individually frozen at $-80^{\circ} \mathrm{C}$. Whole individuals were homogenized cryogenically to a powder using a MixerMill 400 (Retsch® Solutions in Milling and Sieving, Hann, Germany) under liquid nitrogen and one gram wet tissue was weighed for PbTx extraction. For samples from October 2011 through December 2012 archived freeze-dried tissue was used following the same extraction method using wet to dry weight ratios to determine weight for each individual (Dr. Leanne Flewelling, personal communication).

\subsection{Bloom formation}

Karina brevis cell counts were obtained from Florida Wildlife Research Institute monitoring program. More frequent sampling was conducted in the Sanibel / Captiva area than Estero Bay due to the presence of several commercial shellfish beds. Because it is located less than $30 \mathrm{~km}$ north of the study site, monitoring data from Sanibel / Captiva was used to supplement data from the study site.

Onset of the bloom in local waters first occurred in the Sanibel / Captiva area in September 2011 and was observed in Estero Bay (study site) in November 2011 accompanied by a large fish kill consisting primarily of mullet, Mugil cephalus. The bloom persisted into January 2012, but cell counts diminished by the end of the month. This cycle was observed again in green mussel, Perna viridis, during natural Karenia brevis blooms in southwest Florida. Toxicon 97: 46-52 
2012-2013 with an increase in cell concentrations in the Sanibel / Captiva area in late September 2012 and Estero Bay by mid-October 2012. The boom persisted into February 2013 at which time a fish kill comprising several species was observed on Ft. Myers Beach. The bloom peaked in February and diminished by the end of April 2013.

\subsection{Analysis of PbTx in tissues}

All samples were extracted in methanol according to Naar et al. (2002); briefly the protocol is as follows. One gram homogenized wet tissue (or its equivalent in dry tissue) was vortexed well in $80 \%$ methanol, heated in a water bath at $60^{\circ} \mathrm{C}$ for 20 minutes, then transferred to an ice bath for 10 minutes and centrifuged. The supernatant was poured off and stored on ice and these steps repeated on the remaining precipitate. The combined supernatants were brought to a total volume of $10 \mathrm{~mL} 80 \%$ methanol, washed with hexane and stored at $-20^{\circ} \mathrm{C}$ until further analysis.

Brevetoxin ELISA assays were run within seven days of the tissue extraction using a competitive ELISA kit prepared at the University of North Carolina Wilmington according to Griffith et al. (2013). The assay was completed in a 96-well microplate (Nunc-Immunoplate with Maxisorp surface, Thermo Scientific ${ }^{\mathrm{TM}}$, Waltham, Massachusetts). The plate was first coated with $100 \mu \mathrm{L}$ PbTx-3-bovine serum albumin conjugate and incubated on a plate shaker for one hour. The plate was then washed with Phosphate Buffered Saline (PBS) followed by adding a blocking buffer (Superblock ${ }^{\mathrm{TM}}$ dry blend) $(200 \mu \mathrm{L})$ and incubated for 30 minutes on a plate shaker. Following the incubation period the plate was washed with PBS-Tween ${ }^{\mathrm{TM}}$ (buffered detergent). Samples and standards were loaded $(100 \mu \mathrm{L})$ onto the plate in duplicates with the addition of a primary antibody $(100 \mu \mathrm{L})$ and incubated on a plate shaker for 1 hour. The plate was 
washed again with PBS-Tween ${ }^{\mathrm{TM}}$, then a secondary antibody was loaded into the wells $(100 \mu \mathrm{L})$ and again incubated for one hour. Following this incubation the plate was washed with PBSTween $^{\mathrm{TM}}$ and a final PBS wash. Tetramethylbenzidine (TMB) was added as an indicator and the reaction stopped after approximately three minutes using $0.5 \mathrm{M} \mathrm{H}_{2} \mathrm{SO}_{4}$. The absorbance was measured at $450 \mathrm{~nm}$ on a TECAN Genois Pro® plate reader (TECAN Group Ltd., Männedorf, Switzerland). The antibody used detects type-2 brevetoxins which make up $90-95 \%$ of the toxins produced during blooms and include PbTx-2, PbTx-3 and PbTx-9 (Naar et al., 2002). Results are presented as PbTx-3 equivalent to reflect the standard curve used in calculations of PbTx concentrations.

\subsection{Statistical Analysis}

To assess $\mathrm{PbTx}$ concentrations throughout each bloom, paired t-tests were performed to assess differences across time within each collection group. Due to non-normality of the data, the intensity of post-bloom tissue $\mathrm{PbTx}$ accumulation was assessed through integrated trapezoidal area-under-the-curves regarding increase from baseline (AUCi) according to the previously published formula by Pruessner et al. (2003). AUCi was calculated each month separately to compare cumulative increase in PbTx in relation to onset of the bloom between years. The differences in the intensity of PbTx accumulation (AUCi) during corresponding months following K. brevis blooms (2012 and 2013) were evaluated using independent t-tests. All data are presented as means \pm S.D. with statistical significance being defined as $p \leq 0.05$.

\section{Results}

Green mussels accumulated high levels of PbTx in their tissues during a natural exposure to K. brevis. Tissue PbTx concentrations reached a peak in February $2013(137,000 \pm 40,000$ ng 
$\mathrm{g}^{-1} \mathrm{PbTx}-3$ equivalent) following a bloom phase which lasted approximately four months. Peak tissue PbTx concentrations corresponded with peaks in cell counts and duration of bloom (Fig. 1). Tissue toxin concentration remained above the regulatory limit (800 $\mathrm{ng} \mathrm{g}^{-1} \mathrm{PbTx}-3$ equivalent) four to five months post bloom dissipation (Fig. 1A).

The second year of exposure showed a higher peak in toxin concentration compared to the first year (Fig. 1A), coinciding with a more intense and prolonged bloom during the second year (Fig. 1B). Intensity of PbTx accumulation (AUCi) was significantly different between the two bloom years $(p \leq 0.001)$ in which a slower accumulation of $\mathrm{PbTx}$ was observed during the second bloom with a peak in $\mathrm{PbTx}$ tissue concentrations at the end of the bloom after four months of exposure (Fig. 2). During both bloom years, mussels eliminated PbTx while K. brevis was present in the water column, during the waning phase of the bloom in late January 2012 and March - April 2013 (Fig. 1), however this process was slow; PbTx concentration in tissue remained above the regulatory limit until September 2013 and never fell below regulatory limit in 2012 .

In March 2012, a population-wide mass mortality event was observed in the green mussels that decimated the population, leaving only sporadic individuals. During the time of the mortality event the average $\mathrm{PbTx}$ tissue concentration in the green mussels was 15,694 $\pm 3,885$ ng $\mathrm{g}^{-1} \mathrm{PbTx}-3$ equivalent. This mortality event made the collection of adults impossible in April and July 2012 and difficult throughout the summer months. Smaller mortality events continued to be observed throughout the remainder of the monitoring period with the highest mortality observed in the fall of 2012 and 2013 with the return of bloom status in K. brevis. green mussel, Perna viridis, during natural Karenia brevis blooms in southwest Florida. Toxicon 97: 46-52 

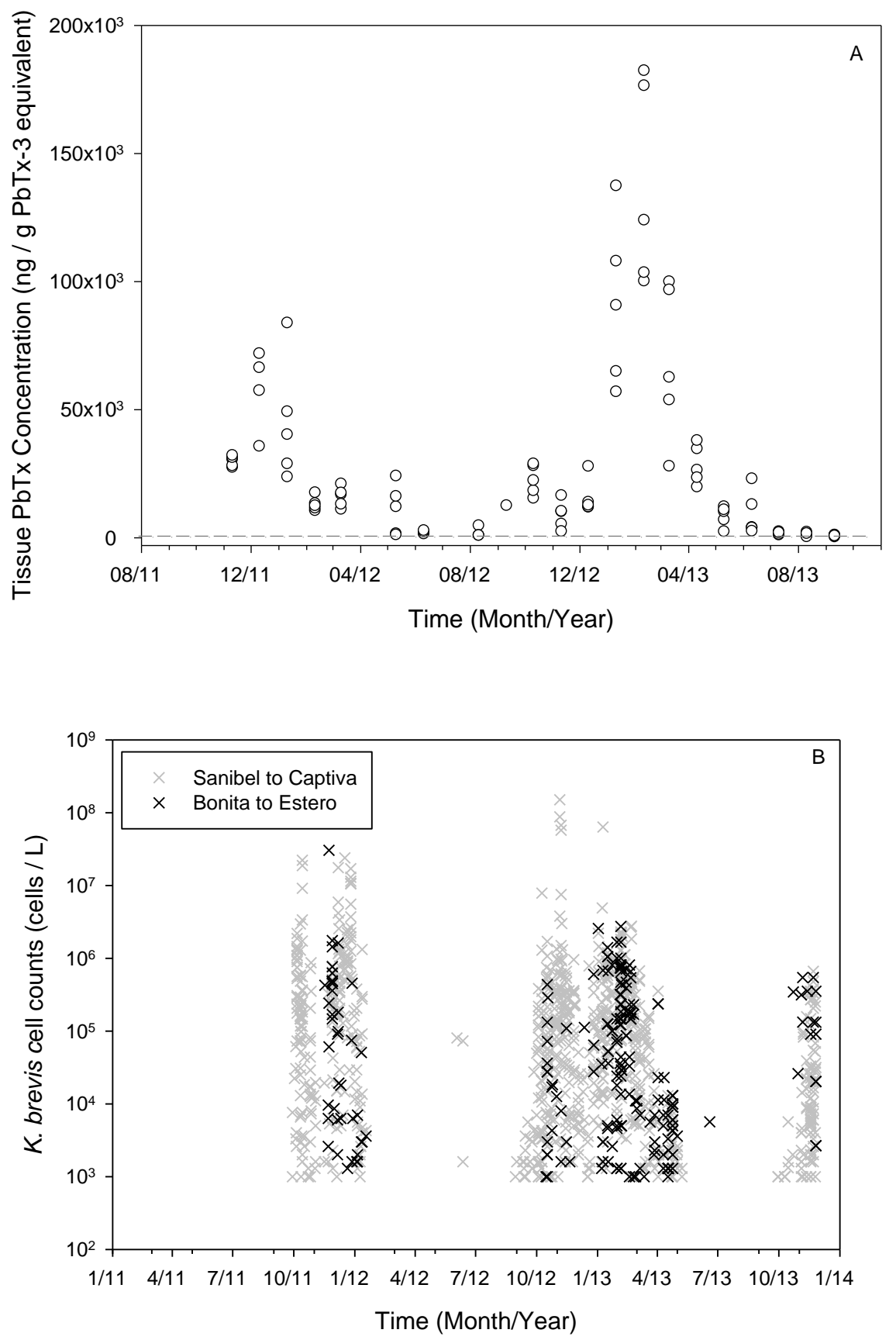

Figure 1: Brevetoxin concentration in individual mussels plotted over time (A). Dashed line indicates the regulatory limit (800 ng g ${ }^{-1} \mathrm{PbTx}-3$ equivalent). Karenia brevis cell counts (log scale) by location over time (B).

McFarland, K., Jean, F., Soudant, P., \& Volety, A.K. (2015). Uptake and elimination of brevetoxin in the invasive green mussel, Perna viridis, during natural Karenia brevis blooms in southwest Florida. Toxicon 97: 46-52 


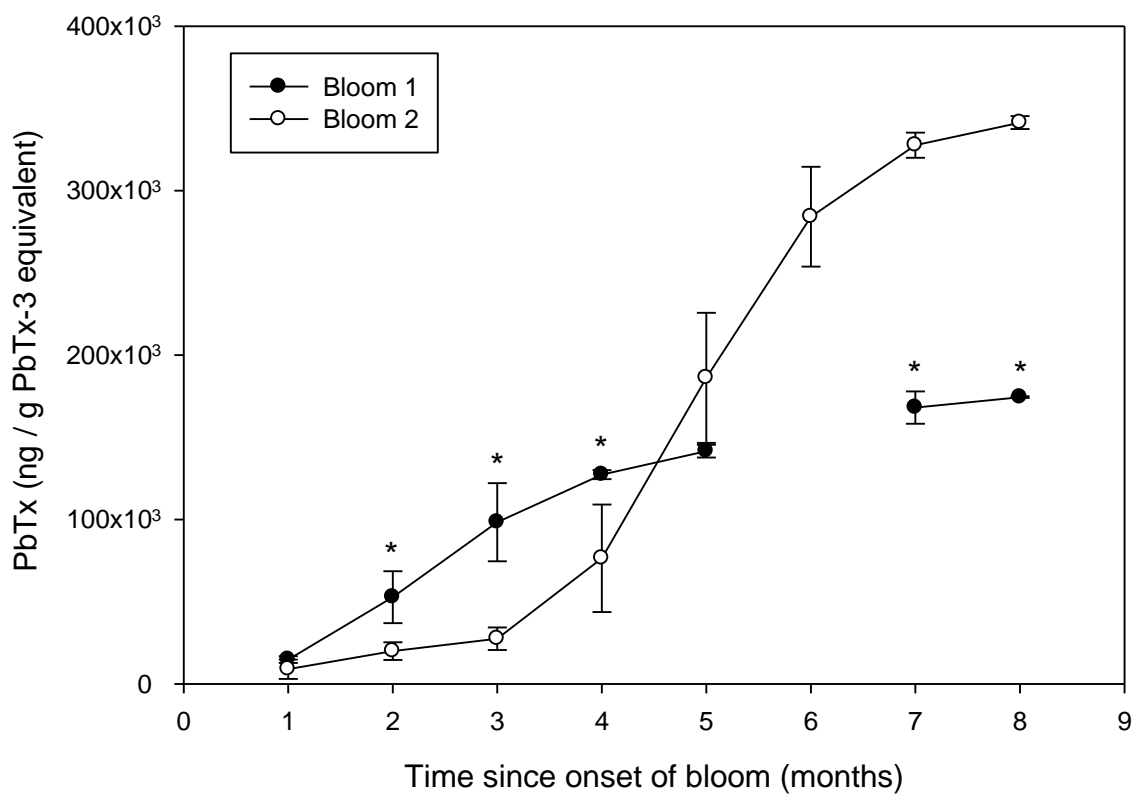

Figure 2: Relative concentrations of $\mathrm{PbTx}$ in green mussel tissues in relation to onset of the bloom for comparison between the two bloom cycles as determined by AUCi analyses. Error bars represent standard deviation and * indicate significant differences between blooms.

Table 1: Southwest Florida bivalve species and the reported time required to depurate $\mathrm{PbTx}$ to levels below the regulatory ( $800 \mathrm{ng} \mathrm{g}^{-1} \mathrm{PbTx}-3$ equivalent) limit following exposure to K. brevis.

\begin{tabular}{lccc}
\hline Species & Depuration Time & Exposure & Source \\
\hline Crassostrea virginica & 2 weeks & lab & Plakas et al., 2002; Griffith et al., 2013 \\
Crassostrea virginica & 2 weeks & field & Plakas et al., 2008 \\
Crassostrea virginica & $2-8$ weeks & field & Morton and Burklew, 1969 \\
Crassostrea virginica & 10 weeks & field & Dickey et al., 1999 \\
Crassostrea virginica & 6 weeks & field & Pierce et al., 2002 \\
Mercenaria mercenaria & 6 weeks & field & Pierce et al., 2002 \\
Mercenaria mercenaria & 2 weeks & lab & Griffith et al., 2013 \\
Perna viridis & $16-20$ weeks & field & This Study \\
\hline
\end{tabular}

McFarland, K., Jean, F., Soudant, P., \& Volety, A.K. (2015). Uptake and elimination of brevetoxin in the invasive green mussel, Perna viridis, during natural Karenia brevis blooms in southwest Florida. Toxicon 97: 46-52 
Table 2: Comparison of green mussel and local oyster average tissue brevetoxin concentrations during the $2011-$ 2012 K. brevis bloom. PbTx concentrations expressed as ng g ${ }^{-1} \mathrm{PbTx}-3$ equivalent.

\begin{tabular}{|c|c|c|c|c|c|}
\hline \multirow[b]{2}{*}{ Month } & \multicolumn{2}{|c|}{$\begin{array}{l}\text { Perna viridis } \\
\text { (this study) }\end{array}$} & \multicolumn{2}{|c|}{$\begin{array}{c}\text { Crassostrea virginica } \\
\text { (Volety et al., unpublished results) }\end{array}$} & \multirow[t]{2}{*}{$\begin{array}{l}\text { Red Tide Status } \\
\text { (FWRI) }\end{array}$} \\
\hline & PbTx & $\mathrm{SD}$ & PbTx & SD & \\
\hline $\begin{array}{l}\text { Oct. } 2011 \\
\end{array}$ & $\overline{\text { N.D. }}$ & & & & \\
\hline Nov. 2011 & 29,696 & 2,051 & & & bloom \\
\hline Dec. 2011 & 57,653 & 15,937 & 33,462 & 10,391 & bloom \\
\hline Jan. 2012 & 44,982 & 23,786 & 7,583 & 2,516 & waning \\
\hline Feb. 2012 & 12,913 & 2,709 & 6,406 & 1,010 & gone \\
\hline Mar. 2012 & 15,694 & 3,885 & 4,159 & 309 & \\
\hline April 2012 & \multicolumn{2}{|c|}{ no sampling * } & 810 & 317 & \\
\hline May 2012 & 10,806 & 9,815 & no & & \\
\hline
\end{tabular}

N.D. indicates that brevetoxin levels were below the detection limit

*April collections could not be completed for $P$. viridis due to a mass mortality event in March 2012 severely reducing the population in addition to poor visibility during SCUBA diving making collections impossible

\section{Discussion}

Through monthly monitoring of PbTx concentrations in the soft tissue of $P$. viridis established in southwest Florida before, during and after two consecutive $K$. brevis blooms, we were able to characterize the uptake and elimination under natural conditions. The data presented here demonstrate that $P$. viridis rapidly accumulated large quantities of $\mathrm{PbTx}$ in their tissues and concentrations remained above the regulatory limit (800 $\mathrm{ng} \mathrm{g}^{-1} \mathrm{PbTx}-3$ equivalent) for an extended period even after bloom dissipation, suggesting the potential for trophic transfer up to five months post bloom.

PbTx tissue concentrations corresponded well with the $K$. brevis cell counts showing peaks in tissue concentrations during and following peaks in water column cell concentrations, suggesting that rapid uptake likely occurred through filtering of whole $K$. brevis cells. Free PbTx in the water column may have contributed to high tissue concentrations. Water column $\mathrm{PbTx}$ concentrations range from $0.4-0.12 \mu \mathrm{g} \mathrm{L}^{-1}$ when cell counts are $\leq 2.4 \times 10^{3}$ cells $\mathrm{L}^{-1}$ (Pierce et al., 2005) and frequently exceed $24 \mu \mathrm{g} \mathrm{L}^{-1}$ during bloom concentrations of $10^{6}$ cells $\mathrm{L}^{-1}$ (Pierce 
et al., 2008). Likewise, Rolton et al. (2015) detected PbTx in K. brevis culture filtrate to range from $5-51 \mu \mathrm{g} \mathrm{L}^{-1}$. The peak in tissue concentration occurred near the end of the bloom indicating continued bioaccumulation of the toxin in mussels, which did not die, leading to increased tissue concentrations through continuous exposure. Tissue $\mathrm{PbTx}$ concentrations were higher in the second year and persisted at elevated levels for an extended period due to the prolonged bloom conditions in 2013 versus 2012 as both elevated exposure intensities and duration affect the accumulation and depuration rate (Morton and Burklew, 1969; Bricelj and Shumway, 1998). However, this peak in tissue concentration occurred late in the bloom cycle after four months of exposure suggesting bioaccumulation and an inability to eliminate toxins during prolonged exposure. Previous exposure history is also a contributing factor to the increased toxin levels in 2013 as tissue toxin concentrations never fell below the regulatory limit following the 2011 - 2012 bloom. In June 2012, K. brevis cell counts reached bloom concentrations for several days at which time it appears the uptake rate exceeded the elimination rate resulting in a small spike in tissue $\mathrm{PbTx}$ concentration, prolonging the elimination period.

While PbTx accumulation and elimination has not previously been studied in P. viridis, evidence for metabolism / biotransformation of $\mathrm{PbTx}$ has been found in several bivalve species including the closely related New Zealand green-lipped mussel Perna canaliculus (Ishida et al., 2004a, 2004b; Ishida et al., 1995; Morohashi et al., 1995; Murata et al., 1998; Nozawa et al., 2003). In both field and controlled laboratory exposures, $P$. canaliculus, showed both an accumulation of PbTx and metabolism from PbTx-2 (most prevalent in the K. brevis cell) to PbTx-3 and BTX-5 at rates dependent upon the intensity and duration of exposure (Ishida et al., 2004a, 2004b). 
When compared with native Florida bivalves, oysters and clams, C. virginica and $M$. mercenaria, $P$. viridis appear to accumulate higher PbTx concentrations and demonstrate slower elimination rates. These local bivalves have been shown to accumulate $\mathrm{PbTx}$ with high survival and rapid depuration rates of $2-8$ weeks (Table 1) (Morton and Burklew, 1969; Steidinger and Ingle, 1972; Plakas et al., 2002; Plakas et al., 2004; Plakas et al., 2008; Bricelj et al., 2012; Griffith et al., 2013). Crassostrea virginica sampled from Pine Island Sound, just $30 \mathrm{~km}$ north of Estero Bay, during the bloom of 2011 - 2012 were shown to reach a peak in PbTx levels averaging approximately 35,000 $\mathrm{ng} \mathrm{g}^{-1} \mathrm{PbTx}-3$ equivalent but exhibited a rapid initial elimination rate, decreasing to $7,500 \mathrm{ng} \mathrm{g}^{-1} \mathrm{PbTx}-3$ equivalent just two weeks after bloom dissipation and dropped below the regulatory limit within $2 \frac{1}{2}$ months (Volety et al., unpublished results). Perna viridis sampled from Estero Bay during this period exhibited nearly double $\left(\sim 58,000 \mathrm{ng} \mathrm{g}^{-1}\right.$ PbTx-3 equivalent) the PbTx concentrations of $C$. virginica (Table 2) and did not fall below the regulatory limit before the return of bloom conditions in October 2012 and a second exposure period.

Field monitoring of bivalves during red tide events in Tampa Bay, Florida have reported tissue concentrations in $C$. virginica ranging from 2,800 - 16,500 $\mathrm{ng} \mathrm{g}^{-1}$ (Pierce et al., 2002; Plakas et al., 2008) to as high as 28,660 - 80,000 ng g-1 (Dickey et al., 1999; Weidner et al., 2002) and M. mercenaria ranging from 1,800 - 6,600 $\mathrm{ng} \mathrm{g}^{-1}$ (Poli et al., 2000; Pierce et al., 2002; Weidner et al., 2002). In controlled exposures, Griffith et al. (2013) found $C$. virginica and $M$. mercenaria to reach 2,000 and 1,000 $\mathrm{ng} \mathrm{g}^{-1}$, respectively after eight days of exposure with acute daily dosing of $5 \times 10^{5}$ cells $\mathrm{L}^{-1}$, whereas Plakas et al. (2004) reported tissue concentrations in $C$. virginica of $740 \mathrm{ng} \mathrm{g}^{-1}$ after only two doses of $10^{4}$ cells $\mathrm{L}^{-1}$ over 48 hours. Concentrations observed in $P$. viridis tissues are higher than those observed in local species. This is likely due to green mussel, Perna viridis, during natural Karenia brevis blooms in southwest Florida. Toxicon 97: 46-52 
a combination of several factors including differences in metabolic activity (uptake, ingestion, and assimilation rates), growth rates, energy turnover, and / or reduced mechanism for “detoxifying" / metabolizing PbTx which could lead to increased tissue damage and physiological impairment. Additionally, PbTx's are lipophilic, thus both lipid composition and lipid turnover rate will play a role in the accumulation and elimination rates and will vary between species and within species at different times of the year or reproductive cycle (Svensson and Förlin, 2004)

Previous work has shown several mussel species to rapidly accumulate high concentrations of toxins produced by HAB's compared to many oyster and clam species (Ingham et al., 1986; Shumway and Cucci, 1987; Shumway et al., 1988, 1990, 1995; Bricelj and Shumway, 1998; Lesser and Shumway, 1993). In the Philippines, $P$. viridis was found to be highly toxic with low survival following a Pyrodinium bahamense var. compressa red tide event in 1983 reaching 9,620 MU $100 \mathrm{~g}^{-1}$ saxitoxin (STX) $\left(\sim 18,000 \mathrm{ng} \mathrm{g}^{-1}\right)$ leading to an eight month shellfish ban due to prolonged toxicity (Gacutan et al., 1984) and in more recent blooms, $P$. viridis reached concentrations as high as $90,000 \mathrm{ng} \mathrm{g}^{-1} \mathrm{STX}$, far exceeding the regulatory limit while other local bivalves showed minimal toxicity (Montojo et al., 2010, 2012). Jaafar et al. (1989) reported high tissue STX concentrations in $P$. viridis during a $P$. bahamense bloom in Malaysia reaching 50, $354 \mathrm{ng} \mathrm{g}^{-1}$, but contrary to blooms in the Philippines showed rapid elimination rates.

Species specific metabolism of PbTx has been reported widely throughout the literature (Cummins et al., 1971; Steidinger et al., 1998; Nozawa et al., 2003; Ishida et al., 2004a, 2004b; Abraham et al., 2012; Echevarria et al., 2012) offering a likely explanation to observable differences between $P$. viridis in this study and those reported for $C$. virginica and $M$. green mussel, Perna viridis, during natural Karenia brevis blooms in southwest Florida. Toxicon 97: 46-52 
mercenaria. Indeed, Ishida et al. (2004b) found a significant difference in PbTx metabolism in $P$. canaliculus and Crassostrea gigas, two similar species to those compared in this study, with different concentrations of metabolites found in each indicating similar pathways, but different reaction rates. Crassostrea gigas showed a more rapid transformation of $\mathrm{PbTx}-2$ to $\mathrm{PbTx}-3$ compared to $P$. canaliculus. While both species had PbTx-3, BTX-B1and BTX-B5, $P$. canaliculus also produced BTX-B2, BTX-B3 and BTX-B4, but C. gigas did not (Ishida et al., 2004b; Morohashi et al., 1999; Nozawa et al., 2003). Concentrations of metabolites present may effect tissue retention time between species as different derivatives may be stored differently and in various tissue compartments, thus effecting elimination rates (Echevarria et al., 2012). Detoxification is partially dependent upon the peak tissue concentration (Bricelj and Shumway, 1998) and previous exposure history can affect the uptake kinetics of biotoxins (Shumway and Cucci, 1987). Feeding behavior and metabolic demands play a significant role in differences in accumulation rates between species. Perna viridis has been shown to have high clearance rates compared to C. viriginica (McFarland et al., 2013) suggesting increased exposure due to increased filtration of $K$. brevis cells. Additionally, $P$. viridis has high growth and reproductive rates leading to increased metabolic demands (Rajagopal et al., 2006; Siddall, 1980; Vakily, 1989) and increased nutrient requirements which may increase filtration behavior causing increased exposure to the toxin.

As a recently introduced species, $P$. viridis may lack the needed adaptions for rapid $\mathrm{PbTx}$ elimination observed in C. virginica and M. mercenaria, which have a long history of $K$. brevis exposure during which $\mathrm{PbTx}$ tolerance and metabolism may have developed, existing in coastal waters of the eastern US seaboard since the 1800's (NOAA, 2005; Volety et al., 2014). Previously exposed bivalves have shown increased resistance and reduced sensitivity to HAB green mussel, Perna viridis, during natural Karenia brevis blooms in southwest Florida. Toxicon 97: 46-52 
exposure compared to unexposed populations (Shumway and Gainey, 1992). While P. viridis experiences harmful algal blooms in their native range (Gacutan et al., 1984, 1985; Choi et al., 2003; Li et al., 2005; Montojo et al., 2012), exposure to a new toxin may cause reduced physiological function and could cause the widespread mortality observed in southwest Florida. Leverone et al. (2007) observed decreased clearance rates in juvenile $P$. viridis during short term exposure to K. brevis indicating reduced feeding, which may turn lethal if conditions persist. Baker et al. (2012) documented a population-wide mortality event in Tampa Bay following a red tide bloom from which green mussel populations never fully recovered and Gacutan et al. (1984) reported $>90 \%$ P. viridis mortality following a red tide event caused by $P$. bahamense in the Philippines. In the current study, a similar mortality event was observed two months post bloom dissipation, however tissue toxin concentrations were still relatively high $\left(15,700 \mathrm{ng} \mathrm{g}^{-1} \mathrm{PbTx}^{-3}\right.$ equivalent). The lag time between peak tissue $\mathrm{PbTx}$ concentration and the first mortality event indicates that other factors are likely involved. Indeed, it coincided with a major spawning period which may have inflicted additional stress on the animal. Galimany et al. (2008) showed a decreased ability to resume normal tissue function, including paralysis of the adductor muscle and prolonged histopathology in Mytilus edulis which had spawned during a laboratory exposure to Alexandrium fundyense. While the mortality events observed in this study cannot be directly related to $K$. brevis exposure, $P$. viridis had high levels of accumulated toxins in their tissues during the observed mortality indicating the potential for prolonged cumulative effects of high tissue toxin burden and physiological stress. Allelopathic, hemolytic, and other ichthyotoxic compounds produced by $K$. brevis may also contribute to the negative effects observed in marine organisms (Kubanek et al., 2005; Marshall et al., 2005). While prolonged elevated tissue toxin green mussel, Perna viridis, during natural Karenia brevis blooms in southwest Florida. Toxicon 97: 46-52 
levels are of concern for trophic transfer, if the mussels die the risk is reduced and invasive species kept at bay.

\section{Conclusion}

To date, the green mussel populations have not recovered from mortalities observed during red tide events in Estero or Tampa Bay, Florida (Baker et al., 2012; this study). However, not all green mussels died during $K$. brevis exposure as collections of adults were made in the months following the mortality event. Thus, seemingly normal mussels may contain high levels of $\mathrm{PbTx}$ for long periods post bloom posing a threat to both natural marine predators and human consumption. Landsberg et al. (2009) attributed post bloom mortality in several fish species and blue crab to trophic transfer from feeding on benthic fauna and post bloom dolphin mortalities in 2004 to trophic transfer from toxic fish. Brand and Compton (2007) noted an increase in the presence of sublethal or background concentrations of $K$. brevis which may be contributing to prolonged tissue toxins post bloom and several studies have noted the persistence of $\mathrm{PbTx}$ in marine sediments and seagrass epiphytes (Shumway and Cucci, 1987; Mendoza et al., 2008). Additionally, whole cell and temporary encystment of toxic dinoflagellates have been observed in bivalve biodeposits following exposure leading to increased risk for transport and increased exposure to benthic organisms via deposition into the sediments (Hégaret et al., 2008). Even at low tissue concentrations, this persistence allows for long term exposure to higher trophic levels through biomagnification post bloom (Rounsefell and Nelson, 1966; Landsberg, 2002;

Flewelling et al., 2005). Animals that prey directly on benthic filter feeders including gastropods, crab, fish and water birds are at risk of exposure and may pose a threat to higher trophic levels through trophic transfer of the toxins by themselves becoming prey (Shumway et al., 1995; Pierce et al., 2002; Flewelling et al., 2005; Hégaret et al., 2008; Bricelj et al., 2012). green mussel, Perna viridis, during natural Karenia brevis blooms in southwest Florida. Toxicon 97: 46-52 
This study has demonstrated the natural accumulation and depuration rates of local $P$. viridis populations with $\mathrm{PbTx}$ concentrations and depuration periods exceeding that of native shellfish in southwest Florida. Further research on the potential trophic transfer from contaminated mussels to commercially important fish and crab is vital to monitoring the bloom and post bloom risks. Additionally, as $P$. viridis is an edible species, both monitoring and public awareness are essential to prevent cases of NSP during post bloom periods in which mussels may still be toxic.

\section{Acknowledgements}

The authors would like to thank David Segal and Bob Wasno for instrumental aid in the collection and processing of mussels. The Coastal Watershed Institute and Vester Marine Field Station staff, with special thanks to Lesli Haynes and Lindsay Castret, for aid throughout the project. We also thank Aaron Slusher and Dr. Darren Rumbold for critical review of early versions of the manuscript. Funding was provided by LabexMer French project (ANR-10LABX-19-01), the South Florida Water Management District, West Coast Inland Navigation District, Marco Island Shell Club, and the U.S. Department of Education under a Congressionally-directed grant (P116Z090117) to A.K. Volety. However, the contents do not necessarily represent the policy of the U.S. Department of Education, and you should not assume endorsement by the Federal Government.

\section{Literature Cited}

Abraham, A., Wang Y., El Said, K.R., Plakas S.M., 2012. Characterization of brevetoxin metabolism in Karenia brevis bloom-exposed clams (Mercenaria sp.) by LC-MS/MS. Toxicon 60, 1030-1040.

Adams, J., Seaton, D., Buchana, J., Longbottom, M., 1968. Biological observations associated with the toxic phytoplankton bloom off the east coast. Nature 220, 24-25.

Baden, D., 1989. Brevetoxins: unique polyether dinoflagellate toxins. FASEB Journal 3, 18071817. 
Baker, P., Fajans, J.S., Baker, S.M., 2012. Habitat dominance of a nonindiginous tropical bivalve, Perna viridis (Linnaeus, 1758), in a subtropical estuary in the Gulf of Mexico Journal of Molluscan Studies 78, 28-33.

Brand, L.E., Compton, A., 2007. Long-term increase in Karenia brevis abundance along the Southwest Florida Coast. Harmful Algae 6, 232-252.

Brand, L.E., Campbell, L., Bresnan, E., 2012. Karenia: The biology and ecology of a toxic genus. Harmful algae 14, 156-178.

Bricelj, V.M., Shumway, S.E., 1998. Paralytic shellfish toxins in bivalve molluscs: occurrence, transfer kinetics, and biotransformation. Reviews in Fisheries Science 6, 315-383.

Bricelj, V., Haubois, A.G., Sengco, M., Pierce, R., Culter, J., Anderson, D., 2012. Trophic transfer of brevetoxins to the benthic macrofaunal community during a bloom of the harmful dinoflagellate Karenia brevis in Sarasota Bay, Florida. Harmful Algae 16, 27-34.

Choi, M.C., Hsieh, D., Lam, P., Wang, W.X., 2003. Field depuration and biotransformation of paralytic shellfish toxins in scallop Chlamys nobilis and green-lipped mussel Perna viridis. Marine Biology 143, 927-934.

Cummins, J.M., Jones, A.C., Stevens, A.A., 1971. Occurrence of toxic bivalve molluscs during a Gymnodinium breve "red tide". Transactions of the American Fisheries Society 100, 112-116.

Davis, C.C., 1948. Gymnodinium brevis sp. Nov., a cause of discolored water and animal mortality in the Gulf of Mexico. Botanical Gazette 358-360.

Dickey, R., Jester, E., Granade, R., Mowdy, D., Moncreiff, C., Rebarchik, D., Robl, M., Musser, S., Poli, M., 1999. Monitoring brevetoxins during a Gymnodinium breve red tide: comparison of sodium channel specific cytotoxicity assay and mouse bioassay for determination of neurotoxic shellfish toxins in shellfish extracts. Natural Toxins 7, 157-165.

Echevarria, M., Naar, J.P., Tomas, C., Pawlik, J.R., 2012. Effects of Karenia brevis on clearance rates and bioaccumulation of brevetoxins in benthic suspension feeding invertebrates. Aquatic Toxicology 106, 85-94.

Flewelling, L.J., Naar, J.P., Abbott, J.P., Baden, D.G., Barros, N.B., Bossart, G.D., Bottein, M.Y.D., Hammond, D.G., Haubold, E.M., Heil, C.A., C.A., Henry, M.S., Jacocks, H.M., Leighfield, T.A., Pierce, R.H., Pitchford, T.D., Rommel, S.A., Scott, P.S., Steidinger, K.A., Truby, E.W., Van Dolah, F.M., 2005. Brevetoxicosis: Red tides and marine mammal mortalities. Nature 435, 755-756.

Forrester, D., Gaskin, J., White, F., Thompson, N., Quick, J., Henderson, G., Woodward, J.C., Robertson, W., 1977. An epizootic of waterfowl associated with a red tide episode in Florida. Journal of Wildlife Diseases, 13, 160-167.

Gacutan, R., Tabbu, M., de Castro, T., Gallego, A., \& Bulalacao, M. (1984). Detoxification of Pyrodinium-generated paralytic shellfish poisoning toxin in Perna viridis from western Samar, 
Philippines. In Toxic Red Tides and Shellfish Toxicity in Southeast Asia (pp. 80-85). Ottawa Canada: International Development Research Center.

Gacutan, R.Q., Tabbu, M.Y., Aujero, E.J., Icatlo Jr, F., 1985. Paraltic shellfish poisoning due to Pyrodinium bahamense var. compressa in Mati, Davao Oriental, Philippines. Marine Biology 87, 223-227.

Galimany, E., Sunila, I., Hégaret, H., Ramón, M., Wikfors, G.H., 2008. Experimental exposure of the blue mussel (Mytilus edulis, L.) to the toxic dinoflagellate Alexandrium fundyense: Histopathology, immune responses, and recovery. Harmful Algae 7, 702-711.

Griffith, A.W., Shumway, S.E., Volety, A. K., 2013. Bioaccumulation and depuration of brevetoxins in the eastern oyster (Crassostrea virginica) and the northern quahog (hard clam, Mercenaria mercenaria). Toxicon 66, 75-81.

Hégaret, H., Shumway, S.E., Wikfors, G.H., Pate, S., Burkholder, J.M., 2008. Potential transport of harmful algae via relocation of bivalve molluscs. Marine Ecology Progress Series 361, 169179.

Ingham, H., Mason, J., Wood, P., 1986. Distribution of toxin in molluscan shellfish following the occurrence of mussel toxicity in North-East England. Nature 220, 25-27.

Ishida, H., Nozawa, A., Totoribe, K., Muramatsu, N., Nukaya, H., Tsuji, K., Yamaguchi, K., Yasumoto, T., Kaspar, H., Berkett, N., 1995. Brevetoxin B1, a new polyether marine toxin from the New Zealand shellfish, Austrovenus stutchburyi . Tetrahedron Letters 36, 725-728.

Ishida, H., Nozawa, A., Nukaya, H., Rhodes, L., McNabb, P., Holland, P.T., Tsuji, K., 2004a. Confirmation of brevetoxin metabolism in cockle, Austrovenus stutchburyi and greenshell mussel, Perna canaliculus, associated with New Zealand neurotoxic shellfish poisoning, by controlled exposure to Karenia brevis culture. Toxicon 43, 701-712.

Ishida, H., Nozawa, A., Nukaya, H., Tsuji, K., 2004b. Comparative concentrations of brevetoxins PbTx-2, PbTx-3, BTX-B1 and BTX-B5 in cockle, Austrovenus stutchburyi, greenshell mussel, Perna canaliculus, and Pacific oyster, Crassostrea gigas, involved neurotoxic shellfish poisoning in New Zealand. Toxicon 43, 779-789.

Jaafar, M., De Silva, M.W.R.N., Sharifuddin, P.H.Y., 1989. Pyrodinium red tide occurrences in Brunei Darussalam, in: Hallegraeff, G.M., Maclean, J.L. (Eds.), Biology, Epidemiology, and Management of Pyrodinium Red Tides: Proceedings of the Management and Training Workshop. Fisheries Department, Ministry Development Bandar Seri Begawan, Brunei Darussalam, p. 9.

Kubanek, J., Hicks, M.K., Naar, J., Villareal, T.A., 2005. Does the red tide dinoflagellate Karenia brevis use allelopathy to outcompete other phytoplankton? Limnology and Oceanography 50, 883-895.

Landsberg, J., 2002. The effects of harmful algal blooms on aquatic organisms. Reviews in Fisheries Science 10, 113-390. 
Landsberg, J., Flewelling, L., Naar, J., 2009. Karenia brevis red tides, brevetoxins in the food web, and impacts on natural resources: Decadal advancements. Harmful Algae 8, 598-607.

Lasker, R., Smith, F.W., 1954. Red tide. Fisheries Bulletin 89, 173-176.

Lesser, M.P., Shumway, S.E., 1993. Effects od toxic dinoflagellates on clearance rates and survival in juvenile bivalve molluscs. Journal of Shellfish Research 12, 377-381.

Leverone, J.R., Shumway, S.E., Blake, N.J., 2007. Comparative effects of the toxic dinoflagellate Karenia brevis on clearance rates in juveniles of four bivalve molluscs from Florida, USA. Toxicon 49, 634-645.

Li, A.M., Yu, P.K., Hsieh, D.P., Wang, W.X., Wu, R.S., Lam, P.K., 2005. Uptake and depuration of paralytic shellfish toxins in the green-lipped mussel, Perna viridis: A dynamic model. Environmental Toxicology and Chemistry 24, 129-135.

Marshall, J.A., Ross, T., Pyecroft, S., Hallegraeff, G., 2005. Superoxide production by marine microalgae. Marine Biology 147, 541-549.

McFarland, K., Donaghy, L., Volety, A. K., 2013. Effect of acute salinity changes on hemolymph osmolality and clearance rate of the non-native mussel, Perna viridis, and the native oyster, Crassostrea virginica, in Southwest Florida. Aquatic Invasions 8, 299-310.

McFarren, E., Tanabe, H., Silva, F., Wilson, W., Campbell, J., Lewis, K.. 1965. The occurrence of a ciguatera-like poison in oysters, clams, and Gymnodinium breve cultures. Toxicon 3, 111123.

Mendoza, W.G., Mead, R.N., Brand, L.E., Shea, D., 2008. Determination of brevetoxin in recent marine sediments. Chemosphere 73, 1373-1377.

Montojo, U., Romero, M., Borja, V., Sato, S., 2010. Comparative PSP toxin accumulation in bivalves, Paphia undulata and Perna viridis in Sorsogon Bay, Philippines, Proceedings of the seventh international conference on molluscan shellfish safety. IFREMER Nantes, pp. 49-55.

Montojo, U.M., Romero, M.L.J., Borja, V.M., Cayme, M.F., Sato, S., Kodama, M., Fukuyo, Y., 2012. Vulnerability of tropical shellfishes against PSP contamination during bloom of Pyrodinium bahamense var. compressum. Coastal Marine Science 35, 64-66.

Morohashi, A., Satake, M., Murata, K., Naoki, H., Kaspar, H.F., Yasumoto, T., 1995. Brevetoxin B3, a new brevetoxin analog isolated from the greenshell mussel Perna canaliculus involved in neurotoxic shellfish poisoning in New Zealand. Tetrahedron Letters 36, 8995-8998.

Morohashi, A., Satake, M., Naoki, H., Kasper, H. F., Oshima, Y., Yasumoto, T., 1999. Brevetoxin B4 isolated from greenshell mussels Perna viridis, the major toxin involved in nuerotoxic shellfish poisoning in New Zealand. Natural Toxins, 7, 45-48.

Morton, R.A., Burklew, M.A., 1969. Florida shellfish toxicity following blooms of the dinoflagellate, Gymnodinium breve. Marine Research Laboratory, Florida Department of Natural Resources. 
Murata, K., Satake, M., Naoki, H., Kaspar, H. F., Yasumoto, T., 1998. Isolation and structure of a new brevetoxin analog, brevetoxin B2, from greenshell mussels from New Zealand. Tetrahedron Letters 54, 735-742.

Naar, J., Bourdelais, A., Tomas, C., Kubanek, J., Whitney, P.L., Flewelling, L., Steidinger, K., Lancaster, J., Baden, D.G., 2002. A competitive ELISA to detect brevetoxins from Karenia brevis (formerly Gymnodinium breve) in seawater, shellfish, and mammalian body fluid. Environmental Health Perspectives 110, 179.

Naar, J.P., Flewelling, L.J., Lenzi. A., Abbott, J.P., Granholm, A., Jacocks, H.M., Gannon, D., Henry, M., Pierce, R., Baden, D.G.. 2007, Brevetoxins, like ciguatoxins, are potent ichthyotoxic neurotoxins that accumulate in fish. Toxicon 50, 707-723.

National Oceanic and Atmospheric Administration (NOAA) 2005. NOAA fisheries service considers listing eastern oyster as threatened or endangered. Press release NOAA05063. http://www.nefsc.noaa.gov/press_release/2005/ma0507.pdf

Nozawa, A., Tsuji, K., Ishida, H., 2003. Implication of brevetoxin B1 and PbTx-3 in neurotoxic shellfish poisoning in New Zealand by isolation and quantitative determination with liquid chromatography-tandem mass spectrometry. Toxicon 42, 91-103.

Pierce, R.H., Henry, M.S., Dickey, R., Plakas, S., 2002. NSP (Karenia brevis) toxins and metabolites in oysters, clams, and whelks." Harmful Algae 294-296.

Pierce R.H., Henry M.S., Blum P.C., Hamel S.L., Kirkpatrick B., Cheng Y.S., Zhou Y., Irvin C.M., Naar J., Weidner A.., Fleming L.E., Backer L.C., Baden D.G., 2005. Brevetoxin composition in water and marine aerosol along a Florida beach: Assessing potential human exposure to marine biotoxins. Harmful Algae 4:965-972.

Pierce R., Henry M., Blum P., 2008. Brevetoxin abundance and composition during ECOHABFlorida field monitoring cruises in the Gulf of Mexico. Continental Shelf Research 28:45-58.

Plakas, S.M., El Said, K.R., Jester, E.L., Ray Granade, H., Musser, S.M., Dickey, R.W., 2002. Confirmation of brevetoxin metabolism in the Eastern oyster (Crassostrea virginica) by controlled exposures to pure toxins and to Karenia brevis cultures. Toxicon 40, 721-729.

Plakas, S.M., Wang, Z., El Said, K.R., Jester, E.L., Granade, H.R., Flewelling, L., Scott, P., Dickey, R.W., 2004. Brevetoxin metabolism and elimination in the Eastern oyster (Crassostrea virginica) after controlled exposures to Karenia brevis. Toxicon 44, 677-685.

Plakas, S.M., Jester, E.L., El Said, K.R., Granade, H.R., Abraham, A., Dickey, R.W., Scott, P.S., Flewelling, L.J., Henry, M., Blum, P., 2008. Monitoring of brevetoxins in the Karenia brevis bloom-exposed Eastern oyster (Crassostrea virginica). Toxicon 52, 32-38.

Poli, M.A., Musser, S.M., Dickey, R.W., Eilers, P.P., Hall, S., 2000. Neurotoxic shellfish poisoning and brevetoxin metabolites: a case study from Florida. Toxicon 38, 981-993. 
Pruessner, J.C., Kirschbaum, C., Meinlschmid, G., Hellhammer, D.H., 2003. Two formulas for computation of area under the curve represent measures of total hormone concentration versus time-dependent change. Psychoneuroendochinology 28, 916-931.

Rajagopal, S., Venugopalan, V.P., van der Velde, G., Jenner, H.A., 2006. Greening of the coasts: a review of the Perna viridis success story. Aquatic Ecology 40, 273-279.

Ray, S. M., Wilson, W. B., 1957. Effects of unialgal and bacteria-free cultures of Gymnodinium brevis on fish, and notes on related studies with bacteria. Fishery Bulletin of the Fish and Wildlife Service, 57, 469-496.

Rounsefell, G.A., Nelson, W.R., 1966. Red-tide research summarized to 1964: Including an annotated bibliography. US Department of the Interior, Bureau of Commercial Fisheries.

Rolton A (2015) Impacts of Karenia brevis on bivalve reproduction and early life history. Université de Bretagne Occidentale. PhD thesis.

Shumway, S.E., Cucci, T.L., 1987. The effects of the toxic dinoflagellate Protogonyaulax tamarensis on the feeding and behaviour of bivalve molluscs. Aquatic Toxicology 10, 9-27.

Shumway, S.E., Hurst, J., Sherman-Caswell, S., 1988. Paralytic shellfish poisoning in Maine: monitoring a monster. Journal of Shellfish Research 7, 643-652.

Shumway, S.E., Barter, J., Sherman-Caswell, S., 1990. Auditing the impact of toxic algal blooms on oysters. Environmental Auditor 2, 41-56.

Shumway, S.E., Gainey, L.F., 1992. A review of physiological effects of toxic dinoflagellates on bivalve molluscs. In Proceedings of Ninth International Malacology Congress 357-362.

Shumway, S., Van Egmond, H., Hurst, J., Bean, L., 1995. Management of shellfish resources, in: Hallegraeff, G.M., Anderson, D., Cembella, A.D. (Eds.), Manual on Harmful Marine Microalgae UNESCO, Paris, pp. 433-461.

Siddall, S.E. 1980, A clarification of the genus Perna (Mytilidae). Bulletin of Marine Science 30, 858-870.

Steidinger, K., Burklew, M., Ingle, R., 1973. Effects of Gymnodinium breve toxin on estuarine animals. In Marine Pharmacolognosy 179-202. New York: Acedemic Press.

Steidinger, K.A. Ingle, R.M., 1972. Observations on the 1971 summer red tide in Tampa Bay, Florida. Environmental Letters 3, 271-278.

Steidinger, K., Carlson, P., Baden, D., Rodriguez, C., Seagle, J., 1998. Neurotoxic shellfish poisoning due to toxin retention in the clam Chione cancellata. Harmful Algae 457-458.

Svensson, S., Förlin, L., 2004. Analysis of the importance of lipid breakdown for elimination of okadaic acid (diarrhetic shellfish toxin) in mussels, Mytilus edulis: results from a field study and a laboratory experiment. Aquatic Toxicology, 66(4), 405-418.

doi:10.1016/j.aquatox.2003.11.002

McFarland, K., Jean, F., Soudant, P., \& Volety, A.K. (2015). Uptake and elimination of brevetoxin in the invasive green mussel, Perna viridis, during natural Karenia brevis blooms in southwest Florida. Toxicon 97: 46-52 
Tester, P.A., Turner, J.T., Shea, D., 2000. Vectorial transport of toxins from the dinoflagellate Gymnodinium breve through copepods to fish. Journal of Plankton Research 22, 47-62.

Vakily, J., 1989. The biology and culture of mussels of the genus Perna. The WorldFish Center.

Volety, A. K., Haynes, L., Goodman, P., Gorman, P., 2014. Ecological condition and value of oyster reefs of the Southwest Florida shelf ecosystem. Ecological Indicators 44, 108-119.

Weidner, A.L., Naar, J., Steidinger, K., Pierce, R., Henry, M.,Flewelling, L., Baden. D.G., 2002. Variability of brevetoxin accumulation levels within individual shellfish during Karenia brevis bloom. Harmful Algae 485-487. 